\title{
ROLA CZASOPISM LITERACKICH W KSZTAŁTOWANIU OBRAZU LITERATURY OBCEJ. PRZYPADEK LITERATURY QUEBECKIEJ W POLSCE
}

\begin{abstract}
Zarys treści: Nieznana szerzej w Polsce literatura quebecka przedstawiona została kompleksowo w jedynym dotychczas wydanym numerze „Literatury na Świecie” (1984), poświęconym w całości literaturze Belle Province. Niniejsza analiza stanowi próbę odpowiedzi na pytanie, jaką rolę odgrywają współcześnie czasopisma publikujące przekłady literatury obcej i jak dalece wpływają na kreowanie jej obrazu. Szczególnie ważne jest to, że ukazują daną literaturę w szerszym kontekście, drukując także teksty kulturo- i literaturoznawcze. Tak skonstruowane czasopismo literackie przybliża zatem daną literaturę, tworząc jednocześnie jej obraz w oczach czytelników wywodzących się z kultury docelowej.
\end{abstract}

Słowa kluczowe: przekład literacki; kultura; kontekst kulturowy

iteratura quebecka w Polsce to przede wszystkim dziewięć spolszczonych powieści, pięć sztuk teatralnych, antologia poezji oraz antologia współczesnej noweli quebeckiej, a także - poza pojedynczymi utworami opublikowanymi w rozmaitych periodykach - jedno czasopismo literackie poświęcone w całości literaturze Belle Province.

W niniejszym szkicu spróbujemy odpowiedzieć na pytanie, jaką rolę odgrywają współcześnie czasopisma publikujące przekłady literatury obcej i jak dalece wpływają na kreowanie jej obrazu. Ukażemy także rolę przekładu wzbogaconego o teksty kulturo- i literaturoznawcze, które zazwyczaj towarzyszą przekładom w czasopismach literackich. Za przykład posłuży lipcowy numer „Literatury na Świecie” z 1984 roku, w całości poświęcony literaturze rodem z Quebeku ${ }^{1}$.

${ }^{1} \mathrm{~W}$ centrum zainteresowania umieszczamy zatem tylko literaturę quebecką i jej wybraną 
Na początek wyjaśnienie terminologiczne, które ma istotne znaczenie dla dalszych rozważań. W poniższej analizie posługujemy się terminem „literatura quebecka", jako że takie określenie jest powszechnie stosowane wśród krytyków oraz samych twórców w Quebeku od czasów Spokojnej Rewolucji. Wspomnieć jednak trzeba o terminologicznej niepewności i doniosłości wyboru odpowiedniego określenia, o której pisał zresztą Józef Kwaterko, autor najpełniejszego jak dotąd opracowania w języku polskim dotyczącego frankofońskiej literatury Quebeku i Karaibów:

Zważywszy na świadomość komplikacji, a nawet wyczuwalną nadwrażliwość, jaka cechuje stosunek wielu autorów do języka francuskiego, literatury te trudno dziś określać przez wygodne niegdyś peryfrazy, takie jak „literatury ekspresji francuskiej”, „języka francuskiego” czy „francuskojęzyczne”. Kojarzą się one bowiem - nieświadomie lub podświadomie - z „francuskim” jako językiem normatywnym lub modelowym, organicznie związanym z Francją (Kwaterko 2003: 17).

Sytuacja komplikuje się dodatkowo w przypadku nazewnictwa w języku polskim. Po pierwsze pojawia się problem czysto językowy. Jak stwierdził we wstępie do Antologii współczesnej noweli quebeckiej Krzysztof Jarosz,

[p] olskie słowniki informują, że od nazwy „Québec” nie tworzy się przymiotników, co przy pisaniu tekstu wymagającego wielokrotnego użycia przymiotnika ukutego od tej nazwy własnej jest rzeczą niemożliwą. Stąd zasadne, jak nam się wydaje, stworzenie połowicznie spolszczonego przymiotnika „quebecki” (Jarosz w: Jarosz, Warmuzińska-Rogóż 2011: 7).

Do sprawy czysto językowej należy dołożyć problem braku wiedzy wśród czytelników polskich, bardzo rzadko bowiem dzieła kanadyjskie w wydaniu francuskojęzycznym są identyfikowane jako quebeckie - przeciętny polski czytelnik nie czyni rozróżnienia na anglo- czy też francuskojęzyczne dzieła kanadyjskie, nie mówiąc już o rozróżnieniu na dzieła quebeckie, a więc tworzone w języku francuskim przez autorów z Quebeku, oraz literaturę frankofońską, która powstała poza Quebekiem, np. w Akadii, Ontario, Saskatchewan, Manitobie czy Albercie. Dla polskiego czytelnika wszystko, co napisali twórcy pochodzący z Kanady, to dzieła kanadyjskie. Tę terminologiczną nie-

odsłonę w postaci lipcowego numeru „Literatury na Świecie” z 1984 roku. Bardziej globalną wizję literatury kanadyjskiej, zarówno anglo- jak i francuskojęzycznej, w „Literaturze na Świecie” w latach 1971-2010 ukazuje w swym artykule Joanna Jakubowska-Cichoń (2013). 
precyzyjność potęguje zresztą Polska Bibliografia Literacka, w której mowa jedynie o literaturze kanadyjskiej, skądinąd słusznie, identyfikacja bowiem odbywa się tam na podstawie przynależności państwowej. Analogicznie dokonuje się tego w większości opracowań bibliotecznych, a także w opisach księgarskich (por. Warmuzińska-Rogóż 2011).

Wróćmy jednak do czasopism literackich. Chronologicznie po raz pierwszy literatura quebecka zaistniała na łamach „Twórczości” (1978, nr 6/395). Następnie literaturą tą zainteresował się „Dialog” (1979, nr 2), w którym opublikowano dramat Gratiena Gélinasa Sami porządni ludzie (Bousille et les justes) w przekładzie Jerzego Lisowskiego i Marty Skibniewskiej. „Dialog" powrócił zresztą do quebeckiego teatru w 1990 roku (nr 8), publikując Siostrzyczki Michela Tremblaya, oraz w 1994 roku (nr 11) wraz z tekstem W najlepszej wierze, także autorstwa Michela Tremblaya (przekład obu sztuk - Józef Kwaterko). W zasadzie numer 7 (156) „Literatury na Świecie” z 1984 roku jest jedynym poświęconym w całości literaturze quebeckiej. W 1998 roku ukaże się jeszcze numer poświęcony Kanadzie („Literatura na Świecie” 1998, nr 4-5/321-322), niemniej jednak Quebec jako taki w nim nie zaistnieje. Pojedyncze teksty ukazały się także w innych periodykach: m.in. opowiadanie Nieznany dybuk (tytuł oryginalny: Le dibbouk inconnu) Régine Robin ze zbioru L'immense fatigue des pierres (Montreal 1996) w przekładzie Piotra Sadkowskiego ukazało się w „Kwartalniku Literackim TEKA” (2005/2006, nr 5-6). Poza Nieznanym dybukiem w polskim przekładzie wyszło inne opowiadanie z tego zbioru: Gratok. Język życia i język śmierci (przekł. Bella Szwarcman-Czarnota, „Midrasz” 2000, nr 9/41). Ponadto w „Midraszu” (2001, nr 3/47), także w przekładzie Belli Szwarcman-Czarnoty, ukazał się fragment książki Régine Robin Biały kon Lenina (Le cheval blanc de Lénine ou l'histoire autre, Bruksela 1979).

Posługujemy się tutaj chętnie słowem „czasopismo”, zastanówmy się jednak najpierw, do czego ono się odnosi. Jak podaje Aron, o ile nietrudno zdefiniować czasopismo jako takie ${ }^{2}$, o tyle „czasopismo literackie” jest dużo trudniejsze do precyzyjnego opisu. Zdaniem badacza, gdyby przyjąć za pod-

2 „Czasopismo (z ang. review) jest publikacją periodyczną o zmiennej zawartości. Jego periodyczność różni go od książki i od broszury. Sens słowa pokrywa się w zasadzie ze słowem journal [fr. czasopismo, dziennik, gazeta - J.W.-R.], przy czym to ostatnie występuje głównie w znaczeniu «journal quotidien» [fr. gazeta codzienna - J.W.-R], które dawniej nazywano «gazette»”. („La revue (de l'anglais review) est une publication périodique au contenu variable. Sa périodicité la distingue du livre ou de la brochure. Son sens est à peu près celui du mot journal, qui sest, lui, spécialisé dans l'acception «journal quotidien», que l'on appelait auparavant la «gazette»"). Przekład wszystkich cytatów francuskojęzycznych - J.W.-R. 
stawowe kryterium publikowanie literatury, wiele gazet codziennych oraz tygodników mogłoby się zaliczać do czasopism literackich. Gdyby z kolei za warunek uznać konieczność umieszczenia w (pod)tytule słowa „literatura” lub pochodnego, wiele z czasopism literackich należałoby wykluczyć. Zresztą, zdaniem Arona, samo kryterium „publikowania” staje się dzisiaj problematyczne, jeśli weźmie się pod uwagę możliwość zamieszczania tekstów w sieci (por. Aron 2008).

Warto zatem raczej zdefiniować czasopismo literackie za pomocą funkcji, jakie mu się przypisuje. Jak podaje Risteroucci-Rudnicky, czasopismo literackie odgrywa w systemie literackim rolę potrójną. Po pierwsze pomocniczą, pozwalając na propagowanie zarówno krótkich form literackich, takich jak wiersz czy nowela, jak i fragmentów dłuższych tekstów, których przekłady nie miałyby szans ukazać się gdzie indziej (Risteroucci-Roudnicky 2008: 103). Po wtóre pozwala na dotarcie do czytelnika $z$ dyskursem krytycznym na temat literatury. Po trzecie wreszcie jest swoistym wskaźnikiem, który unaocznia siły rządzące na polu literackim, współczesne, często najnowsze tendencje w danej literaturze, przede wszystkim daje możliwość ukazania relacji i interakcji między autorami pochodzącymi z różnych krajów (Risteroucci-Roudnicky 2008: 103). Do tej listy dołączyć można także stwierdzenie Semujangi, że czasopisma „stanowią część procesu uświęcenia danego tekstu jako tekstu literackiego" (Semujanga 1991: 4) . $^{3}$.

W kontekście przekładu, który interesuje nas najbardziej, można mówić o dwóch głównych rodzajach czasopism: tych, które ukazują przekłady danej literatury zawsze w relacji z literaturą kultury rodzimej, oraz o tych, które poświęcone są wyłącznie literaturze obcej (Risteroucci-Roudnicky 2008: 103). W pierwszej grupie często zdarza się, że dany numer czasopisma przedstawia teksty zarówno rodzime, jak i obce, wzbogacając je o informacje, wywiady, analizy. Czasem pojedynczy numer zorientowany jest na danego twórcę. Jeśli chodzi o autorów, rekrutują się oni często spośród specjalistów w dziedzinie danej literatury, badaczy akademickich, także krytyków literackich. Analizy nierzadko dotyczą również zagadnień przekładowych. Bywa też tak, że bezpośrednim impulsem do refleksji nad danym dziełem i całokształtem twórczości danego autora jest ponowny przekład.

Trudno wyobrazić sobie zatem funkcjonowanie danej literatury bez wsparcia czasopism literackich, trudno tym bardziej wyobrazić sobie promocję literatury obcej bez wsparcia czasopism literackich, niezaprzeczalnie bowiem uczestniczą one w propagowaniu nieznanych dzieł, pomagają także

3 „elles font partie des instances de consécration, des écrits de création en textes llittéraires”. 
czytelnikom zaznajomić się z nowymi tendencjami oraz pozwalają dojść do głosu krytykom literackim.

Wydaje się, że podobnymi przesłankami kierują się twórcy istniejącej od 1971 roku „Literatury na Świecie”. Zacytujmy opis ze strony wydawnictwa, przedstawiający zmiany, jakie zaszły po roku 1972:

Wraz ze zmianą formatu z dużego na „kieszonkowy” ukształtował się bardziej wyrazisty charakter pisma. Zamiast almanachu prezentującego rozmaite tendencje współczesnej literatury światowej zaczęły ukazywać się monograficzne numery poświęcone jednemu pisarzowi (Joyce, Nabokov, Beckett, Cortazar, Brodski, Barth, Kafka, Borges, Céline, Plath, Blixen, Henry Miller, Kundera, Havel) bądź prezentacji jakiegoś kręgu kulturowego (Latynosi, Québec, Nowojorczycy, Maghreb, Sycylia) lub zjawiska (numer erotyczny, pijacki, o śmierci, Talmud, herezje, esej francuski, sztuczna inteligencja). ( http://www.literaturanaswiecie.art.pl/historia.htm, podkreślenie moje - J. W.-R.).

Istotną częścią „Literatury na Świecie” są teksty poświęcone komparatystyce i literaturoznawstwu. Poza tym nieodłącznym elementem czasopisma jest krytyka przekładu, dość przypomnieć, że od 1972 roku jury pod kierownictwem Jerzego Lisowskiego przyznawało coroczne nagrody za przekład poezji i prozy. Ważną datą był rok 1994, kiedy pod kierownictwem Piotra Sommera „Literatura na Świecie” zaczęła ukazywać się w dużym formacie i w nowej szacie graficznej. Co ważne, kontynuuje założone wcześniej cele, publikując najciekawsze teksty z literatur światowych oraz zamieszczając krytyczne rozprawy, dyskusje, przekłady i omówienia twórczości translatorskiej. Proponuje też przekładowe ponowienia kanonu (Proust, Kafka, Flaubert). Wszystkie wymienione wcześniej działy wpisują się w model, o jakim wspomina Risterucci-Roudnicky.

Przedstawionemu wzorowi odpowiada także lipcowy numer $\mathrm{z}$ roku 1984, poświęcony w całości literaturze quebeckiej (czyli wpisujący się w zamysł „prezentacji jakiegoś kręgu kulturowego”, jak podaje strona internetowa „Literatury na Świecie”). Szczególnie istotne jest to, że mowa właśnie o literaturze quebeckiej, a nie ogólnie kanadyjskiej czy też francuskojęzycznej literaturze kanadyjskiej ${ }^{4}$. Problem tożsamości jest zresztą jednym z kluczowych dla budowy interesującego nas numeru. Przyjrzyjmy się spisowi treści pod kątem zaprezentowanych tytułów i nazwisk twórców:

${ }^{4}$ Dla porządku odnotujmy, że w roku 1998 ukazał się numer „Literatury na Świecie” w całości poświęcony Kanadzie (nr 4-5), przy czym obecne są w nim wyłącznie teksty anglojęzyczne. 


\begin{tabular}{|c|c|}
\hline \multicolumn{2}{|l|}{ Spis treści } \\
\hline Jacques Brault - ...my jedyni na świecie, przeł. Krystyna Rodows & \\
\hline Jacques Ferron - Konfitury z pigwy, przeł. Krystyna Rodowska & \\
\hline Diane Potvin - „Noc” Jacques'a Ferrona, przeł. Krystyna Rodows & \\
\hline $\begin{array}{l}\text { André Major - Jacques Ferron: W poszukiwaniu kraju niepewneg } \\
\text { dowska }\end{array}$ & przeł. Krystyna Ro- \\
\hline Józef Kwaterko - Literatura quebecka w poszukiwaniu tożsamośc & \\
\hline Gaston Miron - Pobratymiec obu Ameryk, przeł. Krystyna Rodo & vska \\
\hline Elisabeth Bednarski - Dlaczego literatura quebecka, przeł. Anna & Kotalska \\
\hline Współczesna poezja Québecu & \\
\hline Claude Jasmin - Ethel i terrorysta, przeł. Józef Kwaterko & \\
\hline $\begin{array}{l}\text { Rozmowa Pierre Villona z Claude Jasminem - Mam prawo do } m \\
\text { Barbara Okólska }\end{array}$ & oich sprzeczności, przeł. \\
\hline Susanne Lamy - Claude Jasmin: obecność prowokująca, przeł. Ba & bara Okólska \\
\hline Janusz Odrowąż-Pieniążek - Zorza nad Péribonka (fragment ksi & żki) \\
\hline $\begin{array}{l}\text { Mit Marii de Chapdelaine i mit mitu Marii de Chapdelaine, rozm } \\
\mathrm{z} \text { Januszem Odrowążem-Pieniążkiem }\end{array}$ & wa Olgierda Poryckiego \\
\hline Fernand Ouelette - Smutne olbrzymy, przeł. Krystyna Rodowska & \\
\hline Wacław Sadkowski - Kanada: droga wolności & \\
\hline Barbara Okólska - Podwójny pejzaż z białymi ptakami Anne Héb & \\
\hline Józef Kwaterko - Współczesna praca w Québecu & \\
\hline Autorzy tego numeru od „A” do „Z” & \\
\hline Norman Mailer - Starożytne wieczory, przeł. Sławomir Magala & \\
\hline Sławomir Magala - Życie towarzyskie i pozagrobowe & \\
\hline Piotr Siemion - $150 x$ cummings & \\
\hline Piotr Sommer - Jest takatak, takatak, takatak, bo właśnie tak to c & zuje \\
\hline Wacław Sadkowski - Uroki życia (poza)konferencyjnego & \\
\hline Herbert Kuhner - Fredek $z$ getta, przeł. Wacław Sadkowski & \\
\hline Imperator wśród książek (opr. A.K.) & \\
\hline Edward Balcerzan - Niekrytyka, krytyka i autokrytyka przekładu & \\
\hline Iwona Badowska - Jesień wydawnicza we Francji & \\
\hline
\end{tabular}

Spis treści interesującego nas numeru „Literatury na Świecie” świadczy o bardzo spójnej strategii wydawniczej. Tom otwiera przekład wiersza Jacques’a Braulta, będącego niejako wstępem do późniejszego układu całości. Wprowadza on zatem w tematykę quebecką mocno w owym okresie skoncentrowaną na zagadnieniach tożsamościowych. Dalej pojawia się przekład 
tekstu kluczowego dla całego numeru, czyli Konfitur z pigwy Jacques’a Ferrona. Przypomnijmy, chodzi tutaj o drugą wersję Nocy, tekstu, który został opublikowany po raz pierwszy w roku 1965 (Éditions Parti pris), w czasie prawdziwego rozkwitu prozy w Quebeku, naznaczonego takimi nazwiskami jak Marie-Claire Blais, Réjean Ducharme, Hubert Aquin. Zdaniem wielu krytyków La Nuit Jacques’a Ferrona jest jednym z dzieł należących do klasyki. Zmieniona wersja Nocy ukazała się w roku 1972, a jej publikacja była po części reakcją twórcy na wiele ważnych wydarzeń politycznych, jakie zaszły w Quebeku5. Polski przekład tego sztandarowego tekstu uzupełniony został o tekst krytyczny Diane Potvin (Noc Jacques’a Ferrona), dzięki któremu czytelnik zapoznaje się z kulisami powstania tekstu literackiego. Następnie w tekście zatytułowanym Jacques Ferron w poszukiwaniu kraju niepewnego André Major umiejscawia pisarstwo Ferrona w szerszym kontekście historyczno-literackim, społecznym i politycznym. Co ważne dla dalszych rozważań, tekst ten opublikowany został w oryginale w roku 1969. Tę część numeru zamyka studium Józefa Kwaterki zatytułowane Literatura quebecka w poszukiwaniu tożsamości, które pozwala polskiemu czytelnikowi na dostrzeżenie szerszej perspektywy. Tym samym badacz wprowadza nas w meandry kształtowania się literatury pisanej w Kanadzie w języku francuskim (celowo nie używam tu określenia „literatura quebecka”), ukazując procesy historycznoliterackie zarówno w obrębie prozy, jak i poezji i udatnie kreśląc ramy społeczno-polityczne, które nigdzie indziej nie wpływają na kształt tekstów literackich tak mocno jak tutaj. Swe rozważania kończy Kwaterko podsumowaniem ostatniego dziesięciolecia (licząc od roku 1984), który charakteryzuje następująco:

w dziełach pisarzy quebeckich daje się odczuć głęboki kryzys świadomości, wywołany wiekową już zależnością od problematyki narodowej. Tematyka wolnościowa dezaktualizuje się coraz bardziej i zaczyna obumierać (Kwaterko 1984: 150).

Wskazuje zatem nowe ścieżki, wystrzegając się jednak wartościowania tendencji najnowszych.

${ }^{5}$ Chodzi głównie o wydarzenia kryjące się pod nazwą Październik 1970, czyli porwanie brytyjskiego attaché handlowego i jednego z ministrów rządu quebeckiego przez Front Wyzwolenia Quebeku, co doprowadziło m.in. do ogłoszenia ustawy o stanie wojennym narzuconym Quebekowi na wiele miesięcy przez rząd kanadyjski. Co ważne w kontekście tekstu Ferrona, człowiek, który posłużył wcześniej pisarzowi za wzór postaci Franka Archibalda Campbella, opowiedział się po stronie rządu kanadyjskiego. To skłoniło Ferrona do przeformułowania tekstu i wydania go pod zmienionym tytułem, w którym postanowił uwydatnić znaczenie trucizny (stąd tytułowe „konfitury z pigwy”). 
Kolejna całostka tematyczna dotyczy współczesnej poezji quebeckiej. Otwiera ją jeden z ostatnich wierszy Gastona Mirona, jak pisze Józef Kwaterko, „najbardziej charyzmatycznego poety współczesnego Québecu”, Pobratymiec obu Ameryk (przeł. Krystyna Rodowska), w którym poeta rozprawia się z problemem przynależności do kraju (por. Kwaterko 2003: 135-136). W kolejnym tekście krytycznym Elisabeth Bednarski zadaje sobie tytułowe pytanie „Dlaczego literatura quebecka?”, wskazując przede wszystkim na terminologiczną niepewność, o której była mowa na początku naszych rozważań. Opisując specyfikę literatury prowincji, ze szczególnym uwzględnieniem poezji, analizuje kolejno uwidocznione w śródtytułach: motyw kraju, klimat geograficzny, klimat duchowy, „ku pokrzepieniu serc” i język. Takie kompendium wiedzy pozwala czytelnikowi w pełni zrozumieć specyfikę zamieszczonych w dalszej kolejności wierszy zgrupowanych w dziale Współczesna poezja Quebecu. Co ciekawe, autorem części przekładów jest Marek Baterowicz, który rok później przetłumaczy wszystkie wiersze składające się na wydaną pod redakcją Józefa Heisteina Antologię poezji Quebeku (zwróćmy uwagę na ortograficzną niekonsekwencję!). Zresztą część zamieszczonych w tym dziale wierszy znajdzie się później także w antologii (m.in. W zamkniętym domu Saint-Denysa Garneau w przekładzie Baterowicza czy Krzyk rozlepiacza afiszów Paula Chamberlanda - w „LnS”” w przekładzie Aleksandry Olędzkiej-Frybesowej, w antologii w przekładzie Baterowicza pod tytułem Rozlepiacz afiszów ryczy). Część z nich natomiast, aczkolwiek są z pewnością reprezentatywne dla poezji quebeckiej tego okresu, do antologii nie weszło, co po części wynika zapewne $\mathrm{z}$ uwarunkowań pozaliterackich, związanych np. z niemożnością uzyskania praw autorskich, a po części z faktu, że opublikowana w 1985 roku publikacja to polskie wydanie zbioru przygotowanego wcześniej na Węgrzech.

Jak zaznaczyliśmy wcześniej, poza krótkimi formami literackimi czasopisma drukują także fragmenty powieści, które jeszcze nie ukazały się w całości drukiem, lub takich, które choć powinny się ukazać, nie mają na to szans, np. ze względów komercyjnych. W interesującym nas numerze „Literatury na Świecie” znalazł się obszerny fragment powieści Claude’a Jasmina Ethel i terrorysta w przekładzie Józefa Kwaterki. Uzupełnieniem przekładu jest rozmowa Pierre’a Villona z autorem Mam prawo do moich sprzeczności (przeł. Barbara Okólska) z roku 1965 oraz esej Susanne Lamy Claude Jasmin: obecność prowokujaca (przeł. Barbara Okólska), w którym autorka kreśli obraz pisarstwa Jasmina i szerzej traktuje o przełożonej powieści.

„Literatura na Świecie” pokazuje także literaturę quebecką przez pryzmat kultury przyjmującej, drukując fragment książki Mit Marii Chapdelaine 
Janusza Odrowąża-Pieniążka, która ukaże się rok później w Wydawnictwie Iskry (wznowienie w 2007 roku), i proponując wywiad $\mathrm{z}$ autorem.

Dalsza część numeru to teksty niepołączone jakąś główną ideą czy też niezgrupowane w większe całości. Mamy zatem zarówno przekład wiersza Fernanda Ouellette’a (w czasopiśmie nazwisko pojawia się z błędem ortograficznym) Smutne olbrzymy w przekładzie Krystyny Rodowskiej ${ }^{6}$, następnie esej Wacława Sadkowskiego Kanada: droga do wolności, stanowiący - jak pisze autor - „nieambitne streszczenie” $\mathrm{z}$ „publicystycznego punktu widzenia” książki Ricka Salutina z roku 1837 pt. William Lyon Mackenzie and the Canadian Revolution (Toronto 1976), który wprowadza czytelnika w rejony zgoła nieliterackie. Dalej następują dwa teksty: analiza Barbary Okólskiej, tłumaczki wielu wierszy opublikowanych w numerze, na temat twórczości Anne Hébert (Podwójny pejzaż z białymi ptakami Anne Hébert) oraz studium Józefa Kwaterki zatytułowane Współczesna prasa literacka w Quebecu. Część tematyczną numeru zamyka bardzo pożyteczne zestawienie Autorzy tego numeru od $A$ do $Z$.

Przegląd utworów składających się na numer poświęcony literaturze quebeckiej pokazuje, że mamy do czynienia ze zbiorem reprezentatywnym, który wpisuje się w pełni w postulowany przez Risterucci-Roudnicky obraz:

Czasopisma, które stanowią odzwierciedlenie akualnej krytyki, dostarczają szerokiego materiału dla każdego, kto będzie miał ochotę na zapoznanie się ze zmieniającymi się obrazami innego, w odniesieniu do czasu, który zasłania i odsłania idoli, nie pozwalając im, by stali się posągami ${ }^{7}$ (Risterucci-Roudnicky 2008: 108).

Nie ma w „Literaturze na Świecie” wstępu, który by wprowadzał w proponowaną tematykę, niemniej jednak obraz całości wydaje się spójny i bogaty. Jak pisze Semujanga,

[c]zasopismo literackie jest produktem skierowanym do specjalistów, po to by albo zaprzeczyć słuszności dominacji danej kultury i tym samym doprowadzić do uznania nowych kategorii estetycznych, lub też po to by dokonać obserwacji ewolucji poetyckiej (Semujanga 1991: 4) ${ }^{8}$.

${ }^{6}$ Ten sam wiersz w przekładzie Baterowicza pod tytułem Smutni giganci ukaże się rok później w Antologii poezji Quebeku.

7 „Les revues, qui se font lécho d'une critique vivante, livrent un matériau de choix pour qui se plaît à saisir les visages mouvants de l’autre, au gré du temps qui voile et dévoile les idoles, les empêchant de devenir statues."

${ }^{8}$ „Le texte de revue littéraire est une production qui s'adresse aux spécialistes, soit pour 
W kontekście czasopisma literackiego i interesującego nas numeru „Literatury na Świecie" warto posłużyć się wykorzystywanymi już przeze mnie w odniesieniu do Antologii poezji quebeckiej pojęciami dominanty translatorskiej oraz czasoprzestrzeni oryginału i przekładu (por. Warmuzińska-Rogóż 2012). Przypomnijmy: dominanta translatorska to, jak podaje Anna Bednarczyk, „ten element struktury utworu tłumaczonego, który trzeba przełożyć (odtworzyć) w utworze docelowym, aby zachować całokształt jego subiektywnie istotnych cech" (Bednarczyk 1999: 19). O ile trudno zastosować to automatycznie do antologii czy czasopisma literackiego, o tyle warto zastanowić się nad dominantą w kontekście wpływu osób trzecich na kształt globalnie rozumianego przekładu. Pisząc o antologii, Danielle Risterucci-Roudnicky stwierdziła, że nawet jeśli mamy do czynienia $\mathrm{z}$ wydawnictwem „reprezentatywnym", każda antologia pokazuje jedynie pewne fragmenty w stosunku do jakiejś subiektywnej całości (Risterucci-Roudnicky 2008: 125). Fragmenty te składają się na obraz danej literatury, który jednak stworzony zostaje przez pryzmat wyborów autora czy też autorów antologii, których Emmanuel Fraisse, autor bardzo ciekawej pracy na temat antologii we Francji, nazywa „organizatorami z zewnątrz", niezależnie od tego, czy chodzi o anonimowego autora, czy też o pewną grupę autorów, autora i tłumacza w jednym itd. (Fraisse 1997). Następnie dokonany przez niego/nich wybór poddany zostaje przekładowi, który w nieunikniony sposób nacechowany będzie przez postać tłumacza. Wydaje się, że z podobnym zjawiskiem mamy do czynienia w przypadku czasopisma literackiego. Na wybór tekstów tworzących spis treści ma wpływ wiele osób trzecich: redaktorzy czasopisma, współpracujący z nimi krytycy, tłumacze, wreszcie posiadacze praw autorskich do tekstów, które w danym tomie powinni się znaleźć. Należy także rozpatrywać wybór przez pryzmat czynników pozaliterackich: nie możemy zapominać chociażby o czynnikach finansowych. Wydaje się, że czasopismo literackie jest w sytuacji uprzywilejowanej w stosunku do antologii: dla przykładu „Literatura na Świecie” od 1994 roku należy do grupy pism patronackich, wydawanych przez Bibliotekę Narodową i objętych mecenatem Ministerstwa Kultury i Dziedzictwa Narodowego, co powoduje, że względy czysto merkantylne nie wpływają na dobór tekstów, a pamiętajmy, że to właśnie ten czynnik przeważa wciąż przy wyborze tego, co od czasów transformacji ustrojowej trafia w Polsce do druku ${ }^{10}$.

contester la légitimité culturelle dominante, et faire admettre ainsi de nouvelles catégories esthétiques, soit pour faire un constat de l'évolution poétique."

9 "tiers organisateurs”.

${ }^{10}$ Jak stwierdza Skibińska, po okresie, gdy na listach publikacji w Polsce królowała lite- 
Warto także wspomnieć o specyfice czasopisma literackiego, która zasadza się na tym, że teksty stricte literackie stanowią z pewnością ważną jakościowo część spisu treści, ale uzupełnione są zawsze tekstami krytycznymi, które pod względem ilościowym przeważają wręcz nad analizowanymi dziełami czy fragmentami dzieł literackich. Tym samym wybór krytyków wypowiadających się na łamach czasopisma ma znaczenie pierwszorzędne dla kształtu całości danego numeru czasopisma, a co za tym idzie dla obrazu literatury wyjściowej, jaki otrzyma czytelnik przekładów. W przypadku omawianego numeru „Literatury na Świecie” dobór tekstów krytycznych wydaje się jak najbardziej zasadny: przeważają krytycy wywodzący się z samego Quebeku, poza tym swój punkt widzenia przedstawiają uznany polski znawca literatury quebeckiej oraz polska tłumaczka. Tym niemniej, jak każdy wybór, także i ten niesie ze sobą nieunikniony element subiektywny.

Drugim interesującym nas zagadnieniem jest czasoprzestrzeń oryginału i przekładu, definiowana przez Bożenę Tokarz jako różnice w postrzeganiu dzieła literackiego z jednej strony przez autora i czytelnika oryginału, a z drugiej strony przez „drugiego autora” (Legeżyńska 1999), czyli tłumacza, oraz przez czytelnika przekładu. Różnice te wynikają, rzecz jasna, z różnego czasu i miejsca odbioru dzieła literackiego (Tokarz 2010: 10). Tokarz proponuje, by zbadać czasoprzestrzeń $\mathrm{w}$ powiązaniu z samym przedmiotem artystycznym, w kontekście komunikacji (nadawca-odbiorca) oraz przez pryzmat relacji utworu literackiego do rzeczywistości zewnętrznej (Tokarz 2010: 9).

Lipcowy numer „Literatury na Świecie” z roku 1984 ukazuje się w momencie, gdy w Quebeku królują niepodzielnie nowe tendencje: wkracza na scenę literatura neoquebecka („les écritures migrantes”), do głosu wyraźnie dochodzą kobiety, a swe miejsce na scenie literackiej ugruntowuje nowela. Tymczasem zbiór odnosi się głównie do zagadnień tożsamościowych i przemian, jakie wcześniej zaszły w literaturze prowincji. Kluczowy w tym numerze tekst Jacques’a Ferrona Noc pochodzi z 1972 roku, wiele opublikowanych tekstów krytycznych powstało w latach 70. Ma to swoje uzasadnienie: redakcja czasopisma stawia sobie bowiem najwyraźniej za cel ukazanie tego, co nowe, ale jednocześnie już w jakiś sposób uznane i opisane. Można tu zatem mówić o pewnym przesunięciu czasowym, swoistym opóźnieniu w stosunku do tendencji w kulturze wyjściowej. Pamiętajmy, że dany numer stanowi

ratura popularna (bo to ona gwarantuje natychmiastowy zysk), wydawcy zaczęli także zwracać uwagę na dzieła, których wydanie jest - rzecz jasna - opłacalne, ale które także charakteryzują się wartościami estetycznymi i intelektualnymi. Skibińska mówi tu o dwutorowym mechanizmie: gromadzeniu kapitału ekonomicznego oraz sybolicznego (Skibińska 2009: 238). 
zwierciadło tendencji w danym momencie, starzeje się jednak dość szybko. Jest wypadkową opinii krytyków, prądów drogich redaktorowi oraz możliwości wydawniczych. Jak pisze Aron, „[n]a czasopismo składają się kapitał, role, pośrednicy, wzajemne zależności [...]" (Aron 2008) ${ }^{11}$. Stanowi zatem doskonałe wprowadzenie do danej literatury, zdaje sprawę z tego, co dzieje się $\mathrm{w}$ danym okresie, ale jednocześnie powinno odzwierciedlać zmiany zachodzące $w$ procesach historycznoliterackich. Czasopismo literackie spełni zatem swoją rolę tylko wtedy, gdy sięgnie co pewien czas do zasobów wybranej literatury po to, by zaktualizować jej obraz w oczach obiorców kultury przyjmującej. I w przypadku literatury quebeckiej z pewnością byłoby o czym pisać: „écritures migrantes”, nurt feministyczny, powieść miejska, by wymienić jedynie kilka nurtów, które nie są w naszym kraju szczególnie znane. Polskim czytelnikom pozostaje tylko czekać cierpliwie na nową odsłonę czasopisma poświęconego literaturze tworzonej w języku francuskim rodem z Quebeku.

\section{Literatura}

Aron, P., 2008, „Les revues littéraires: histoire et problématique”, [w:] COnTEXTES, http://contextes.revues.org/3813 (dostęp: 24 lipca 2013 r.).

Bednarczyk, A., 2008, W poszukiwaniu dominanty translatorskiej, Warszawa. Dialog 1979, luty, nr 2.

Dialog 1990, sierpień, nr 8.

Dialog 1994, listopad, nr 11.

Fraisse, E.,1997, Les anthologies en France, Paris.

Heistein, J. (red.), 1985, Antologia poezji Quebeku/Anthologie de la poésie québécoise, Wrocław.

Jakubowska-Cichoń, J., 2013, „La littérature canadienne dans la revue polonaise Literatura na Świecie (1971-2010)", [w:] Vers la Réciprocité: Échanges littéraires entre le Canada, la Pologne, la République tchèque et la Roumanie, A. Whitfield (red.), Montréal.

Jarosz, K., Warmuzińska-Rogóż, J., 2011, Antologia wspótczesnej noweli quebeckiej, Katowice.

Kwaterko, J., 2003, Dialogi z Ameryka.. O frankofońskiej literaturze w Quebécu i na Karaibach, Kraków.

Legeżyńska, A., 1999, Tłumacz i jego kompetencje autorskie, Warszawa.

11 „Une revue est donc faite de capitaux, de rôles, d’agents, de relations, et chacun de ces éléments mérite dêtre analysé en corrélation avec les discours qui y sont tenus". 
Literatura na Świecie 1984, nr 7 (156).

Literatura na Świecie 1998, nr 4-5, (321-322).

Risterucci-Roudnicky, D., 2008, Introduction à l'analyse des ceuvres traduites, Paris.

Robin, R., 2001, „Biały koń Lenina”, przekł. B. Szwarcman-Czarnota, [w:] Midrasz, nr 3/47.

Robin, R., 2000, „Gratok. Język życia i język śmierci”, przekł. B. Szwarcman-Czarnota, [w:] Midrasz, nr 9/41.

Robin, R., 2005/2006, „Nieznany dybuk”, przeł. P. Sadkowski, [w:] Kwartalnik Literacki TEKA, nr 5-6.

Semujanga, J., 1991, „Le rôle des revues littéraires et des maisons dédition dans la spécification de la (des) littérature(s) de l'Afrique subsaharienne francophone", [w:] Études littéraires, vol. 24, no 2, s. 99-112.

Skibińska, E., 2009, „Gabrielle Roy et la Pologne: raisons d'une absence”, [w:] Lécho de nos classiques. Bonheur d'occasion et Two solitudes en traduction, A. Whitfied (red.), Ottawa.

Tokarz, B., 2010, Spotkania. Czasoprzestrzeń przekładu artystycznego, Katowice.

Twórczość 1978, nr 6/395.

Warmuzińska-Rogóż, J, 2011, „Kanoniczne dzieła literatury quebeckiej w języku polskim", [w:] Przekład jako produkt i kontekst jego odbioru, I. Kasperska, A. Żuchelkowska (red.), Poznań.

Warmuzińska-Rogóż, J., 2012, „Antologia a przekład: między wyborem autora, redaktora i tłumacza (na przykładzie literatury quebeckiej w Polsce)", [w:] Między oryginałem a przekładem, A. Bednarczyk, J. Brzozowski (red.), Kraków, s. 255-273.

The role of literary journals in shaping the image of a foreign literature. The case of the Quebec literature in Poland

\section{Summary}

The Quebec literature, still not widely known in Poland, has been comprehensively presented in „Literatura na Świecie" in 1984 (Literature in the world) that has been the only issue so far entirely devoted to the literature of La Belle Province. The present analysis is an attempt to answer the question about the role magazines and journals publishing foreign literature translations perform nowadays as well as about the extent of the influence they exert on creating the image of a given literature translated into Polish. It is particularly important that those magazines and journals present 
foreign literatures in wider contexts, and they also publish texts concerning culture and literary studies. A magazine or journal on literary issues that has been structured and arranged in the above manner provides the reader with a closer access to a given literature, concurrently shaping its image in the minds of the target culture readers.

Keywords: literary translation, culture, cultural context

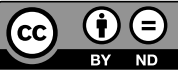

